\title{
THE BEATING OF RODNEY KING: THE DYNAMICS OF BACKFIRE
}

\author{
Brian Martin \\ University of Wollongong \\ Brian Martin \\ School of Social Sciences, Media and Communication \\ University of Wollongong, NSW 2522, Australia \\ phone: +61-2-4228 7860 (home), +61-2-4221 3763 (work) \\ fax: $+61-2-42215341$ \\ bmartin@uow.edu.au \\ http://www.uow.edu.au/arts/sts/bmartin/
}

\begin{abstract}
The 1991 beating of Rodney King by Los Angeles police provides rich case material in how an attack perceived as unjust can backfire. Drawing on nonviolence theory, an original framework is developed to analyze attacks as potential backfires that are usually, but not always, inhibited. Attackers can use a variety of methods to inhibit backfires, including covering up the attack, devaluing the target, reinterpreting the events, using official channels, and using intimidation and bribery. Writings on the Rodney King beating include evidence on the use of each of these methods. Studying the backfire process offers improved understanding on how to oppose unjust attacks.
\end{abstract}


Not long after midnight on March 3, 1991, Rodney King was beaten by officers of the Los Angeles Police Department. King was hit by two high-voltage tasers and then struck dozens of times by metal batons, as well as being kicked, over a period of several minutes. More than 20 police were present at the beating, which was illuminated by floodlights from a police helicopter hovering overhead.

This event probably would have become just another arrest statistic except for the fact that a portion of the incident was captured on videotape by an observer, George Holliday. After the video was screened on television, the "Rodney King beating" became the most well-known case of police use of force in history, with serious adverse effects for the police. The reputation of the LAPD took a battering, as the force was widely perceived to be tolerant of brutality. There were vociferous calls for LAPD Chief Daryl Gates to resign. The four officers directly involved in the beating were charged with assault and brought to trial. Media attention was intense over the following months, with thousands of newspaper articles published as well as extensive coverage by electronic media. Morale in the LAPD was seriously damaged (Cannon 1999; Skolnick and Fyfe 1993, pp. 1-22).

The King beating is an ideal case study for social analysis given the great amount of documentation of the incident and the subsequent media coverage, trials, and riots. Among the studies undertaken are assessments of the context of racism and social control (GoodingWilliams 1993a), examination of the discursive practices of professionals, namely the police (Goodwin 1994), narrative analysis of media stories about the beating (Jacobs 1996, 2000), and study of the effects of the beating on public opinion about racial discrimination (Sigelman et al. 1997). Here, the King beating is analyzed using an original framework: the dynamics of backfire.

If the beating is conceptualized as an attack on King, then it is reasonable to say that the attack backfired: it recoiled adversely on the attackers. That the beating ended up being damaging to the police has been attested by observers of diverse persuasions (e.g., Cannon 1999, p. 228; Skolnick and Fyfe 1993, p. 10) and confirmed by research (Lasley 1994). Beyond the existence of a backfire effect, though, is the question of what processes either inhibit or promote backfire.

To gain insight into the dynamics of backfire, it is valuable to look at other attacks, even though they appear on the surface to be qualitatively different from a police beating. By examining violent assaults are made on peaceful protesters, such as the Sharpeville massacre in 
South Africa in 1960 and the Dili massacre in East Timor in 1991, it is possible to perceive five principal means by which attackers can inhibit a backfire effect:

- covering up the attack;

- devaluing the target;

- reinterpreting the events;

- using official channels to give the appearance of justice;

- using intimidation and bribery.

Challengers can augment the backfire effect by countering these five methods of inhibition, for example by exposing the attack.

Backfire analysis is built on the assumption that reality is socially constructed (Berger and Luckmann 1966). Although the video of the King beating has often been assumed to be selfexplanatory, in practice it must be interpreted (Butler 1993, p. 17; Gooding-Williams 1993b, p. 165). Defenders of the police interpreted the events as a fully justified use of force. Reactions to the King beating were part of a struggle over perceptions of reality and what to do in response to those perceptions. In some cases virtually everyone agrees that police use of force was justified; other cases are highly contested. Due to its prominence and the high level of disputation, the King beating provides exceptionally rich case material for examination.

The analysis here is also compatible with, but different from, the political process model of Ross (2000) for police violence. This model, consisting of the stages of media initiation, arousal, reaction, and outcomes, is descriptive of what can happen after a public case of police violence; backfire analysis draws attention to tactics used by those who stand to gain or lose from outrage over police violence.

In the next section, several historical examples are used to illustrate the five main methods for limiting or amplifying backfire. Subsequent sections apply this framework to the King beating, drawing especially on evidence from a number of books, written from distinctively different perspectives, about the beating. This analysis shows that the framework of backfire is quite fruitful in placing a range of apparently diverse phenomena into a unified picture.

\section{Historical backfires}

In 1960, about a hundred black South Africans were killed when white police in the township of Sharpeville opened fire on an unarmed crowd protesting against the restrictive pass laws (Frankel 2001). What became known as the Sharpeville massacre was disastrous for the South 
African regime, greatly reducing its credibility as a democratic state and leading to a huge upsurge in international solidarity action.

On November 12, 1991, hundreds of people were killed when Indonesian troops opened fire on a peaceful protest at a funeral in Dili, the capital of Indonesian-occupied East Timor (McMillan 1992). A British filmmaker with the pseudonym Max Stahl managed to capture the massacre on film and smuggle the tape out of the country. Shown on television internationally, the so-called Dili massacre had a galvanizing effect on international support for the East Timor liberation movement. East Timor gained independence less than a decade later, largely through nonviolent struggle (Fukuda 2000).

These are two prominent examples of massacres that backfired. In each case, official violence that was intended to crush opposition instead had the opposite effect, namely stimulating more resistance.

Gene Sharp, the world's leading nonviolence researcher, developed the concept of "political jiu-jitsu," a term that makes an analogy to the sport of jiu-jitsu, in which the opponent's strength and force are turned against them (Sharp 1973, pp. 657-703). Political jiu-jitsu occurs when violence used against nonviolent opponents generates outrage and rebounds against the aggressor. The attack can lead to greater support for the challengers among third parties, among some members of the attacker group, and among what Sharp calls the "grievance group," namely those with potential affinity with the target of the attack. He is careful to point out that not all violent attacks lead to political jiu-jitsu; context is important, as is the configuration of forces and tactics used in the struggle.

Sharp's case studies and analysis provide strong support for the view that some attacks can be counterproductive. He restricts his attention to violent assaults on nonviolent protesters, but it is reasonable to presume that the same dynamics can apply to any attack that is seen as unjust or disproportionate. King was certainly not a nonviolent activist - he was speeding, fled police in a high-speed chase, and resisted arrest — but his beating was widely perceived as unjust or disproportionate to anything King had done to the police. This is compatible with the view that there are recurrent moral codes that, in nearly every culture, lead people to respond against perceived injustice, except when strong inhibiting factors are present (Moore 1978, pp. 3-48). This is also compatible with Durkheim's views on norm violation, with the qualification that the norm violation in the sort of cases covered here is by authorities rather than deviant individuals. I have introduced the term "backfire" to refer to the reaction against attacks that are perceived to be unjust or disproportionate; in essence, 
"backfire" is a generalization of Sharp's "political jiu-jitsu" beyond the category of nonviolent action.

Sharp focuses on political jiu-jitsu as an observed phenomenon. Taking a cue from Moore's (1978) discussion of factors that can inhibit reactions against injustice, it is possible to look for factors that inhibit outrage.

One obvious way to inhibit outrage is to hide the attack. The Dili massacre might have received relatively little attention except for the presence of Western journalists and a film that was smuggled out of the country. The Indonesian military, after attacking and occupying East Timor in 1975, had cut off virtually all external communication, thereby reducing awareness of human rights abuses. In 1991, a more liberal policy allowed Western journalists to enter East Timor, setting the stage for exposure of the Dili massacre.

A second way to inhibit outrage is to devalue the target. In the case of the Sharpeville massacre, South African police blamed the event on "agitators" in the crowd, a view adopted by many white South Africans, for whom blacks were seen as inherently inferior. Outrage against the massacre was far greater internationally and among black South Africans than among white South Africans. The commander-in-chief of the Indonesian armed forces denigrated Dili protesters as "scum" and "delinquents" who must be shot (McMillan 1992, p. 162).

A third way to minimize outrage is to reinterpret the events. Even the most brutal attack against a defenseless victim is not self-explanatory: all social phenomena are socially constructed and hence require interpretation. South African authorities claimed that the large crowd at Sharpeville was threatening the safety of police, whereas other observers detected a more playful atmosphere.

In some cases, authorities lie blatantly about events, but in others the attackers and their supporters may genuinely believe an interpretation that justifies the attack. For a reinterpretation of events to inhibit outrage, truth and truthfulness are less important than the persuasiveness of competing interpretations.

A fourth way to reduce outrage is to use official channels to give the appearance that justice is being done. Following the Sharpeville massacre, the South African government set up a commission of inquiry to investigate. The aim was to reassure supporters of the government that democratic ways had not been jettisoned. There was a risk that an official inquiry might come up with damaging findings and make matters worse, so a pliant commissioner was sought, but not one who would be so subservient as to lose all credibility (Frankel 2001, p. 
188). After the Dili massacre, there was an official Indonesian investigation that greatly underestimated the number of casualties but did lead to removal of some officials from their posts. International pressure prompted the Indonesian government to prosecute a few members of the security forces for their role in the massacre; however, their sentences were light (Kohen 1999, pp. 170-71).

A fifth way to inhibit the expression of outrage is to intimidate or bribe targets, participants, and witnesses. After the Sharpeville massacre, police went through the township arresting anyone involved in organizing the protest. So effective was intimidation that very few eyewitnesses to the massacre were willing to testify at the commission of inquiry. More generally, potential defectors among the attackers, such as among police or troops who carry out massacres, are commonly deterred by the implicit or explicit threat of reprisals. Similarly, those who toe the line, such as tame officials who ignore or approve an atrocity, often can look forward to career advantages.

In the tradition of developing grounded theory, I discovered and elaborated these five ways to inhibit outrage by looking at a range of cases, especially at detailed accounts such as Frankel (2001) and at a range of case studies from different fields (Jansen and Martin 2004; Martin 2004; Martin and Wright 2003). Nevertheless, there is a certain logic in the classification. The backfire process can be conceptualized as an event that leads to a perception of a target being attacked unjustly which in turn leads to action. Each of the methods of inhibition engages with a different facet of this process, as shown in Figure 1.

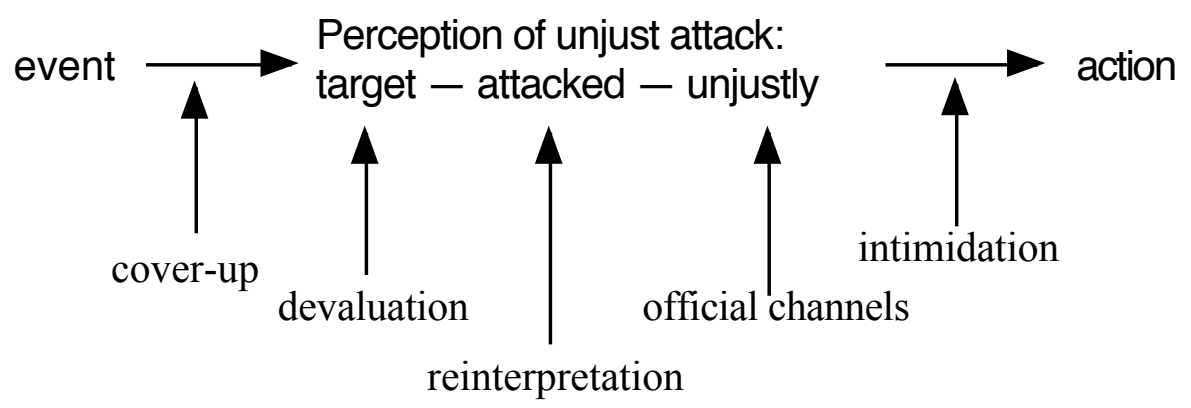

Figure 1. A schematic portrayal of backfire dynamics, with each of five methods of inhibition linked to facets of the backfire process.

Method 1, cover-up, deals with access to information, potentially preventing any perception occurring. Method 2, devaluation of the target, deals with psychology, especially attitudes about just desert, that affect perception of injustice. Method 3, reinterpretation, 
deals with knowledge, meaning, and narrative, again affecting perception of injustice. Method 4, official channels, deals with justice as formally administered, affecting the reaction to injustice. Method 5, intimidation and bribery, deals with the exercise of power, typically affecting willingness to take action against injustice.

The five-method classification has limitations. The methods, in practice, are not fully independent. For example, intimidation can be used to promote cover-up; devaluing the target could be considered to be a facet of reinterpreting the events. Some of the methods can be subdivided. For example, the method of cover-up can be applied to the very existence of an attack, just to the participation of certain parties in the attack, or to the use of intimidation. Any classification scheme is bound to have shortcomings. The test of this scheme is whether it facilitates understanding of new cases, especially those in entirely different domains.

There are correspondences between the five methods for inhibiting public outrage over injustice and psychological mechanisms by which individuals disengage from responsibility for their actions. Bandura (1986, pp. 375-389) lists a number of such psychological mechanisms, such as dehumanizing the victim, euphemistic labeling, and misconstruing the consequences, that can be mapped on the methods of inhibition. Similarly, Sykes and Matza (1957) list five "techniques of neutralization," again as psychological mechanisms for justifying deviant behavior. Of these, denial of responsibility and denial of injury can be categorized as methods of reinterpretation; denial of the victim and condemnation of the condemners can be categorized as methods of devaluation; and appeal to higher loyalties can be categorized as an attempt to replace official channels. Note that the techniques of neutralization apply to deviant individuals whereas the methods for inhibiting outrage are applied here to deviant authorities.

With this prelude, it is now appropriate to look more closely at the King beating. This will be done by examining in some detail each of the five methods of inhibiting outrage, presenting evidence, especially from partisan books about the beating, that illustrates features of the struggle over reactions to the beating.

This is not an attempt to tell "the story" of the King beating, much less to determine "what really happened." Despite the existence of the videotape, the meaning of the events remains contested. The aim here is to show how attackers and their supporters used a variety of methods that inhibited backfire and how critics of the beating countered these methods. 


\section{Cover-up}

The defining feature of the King beating is the availability of a videotape recording the event. As noted by numerous commentators, without the videotape, the beating would have been unlikely to come to public attention (Ogletree et al. 1995, p. 6; Omi and Winant 1993, p. 97; Skolnick and Fyfe 1993, pp. 3, 190). Cover-up, as a means to inhibit backfire, failed spectacularly in King case. Nevertheless, evidence of cover-ups can be found in the King saga.

But first it is worth noting that the usual scenario for cases of police brutality and other misconduct is no publicity and little or no negative consequences for police (Ross 2000, p. 199). For example, in the 1988 "Dalton Avenue incident," 80 Los Angeles police trashed four apartments, destroying property and spraying graffiti, and, according to witnesses, beat many people, but this received little media attention (Lawrence 2000, p. 67). An investigation into police misconduct in the US, stimulated by the King beating, stated:

Many cases of police misconduct take place out of the public eye. Often, there are no witnesses to the incident other than police officers and the victim of the misconduct, and thus no one to corroborate the complainant's account. Representatives of community organizations and legal agencies described the difficulty of pursuing complaints against the police, particularly in the absence of witnesses. Both police and civilians agreed that, if it comes down to a citizen's word against an officer's story, the police version controls. In the vast majority of cases involving one civilian and one officer the complaint is not sustained. (Ogletree et al. 1995, pp. 60-61).

Some of the reported cases of police brutality are far more serious than the King beating and seem to have less justification. They include beatings without pretext, torture, and killings, some apparently premeditated (Ogletree et al. 1995; Skolnick and Fyfe 1993). From the point of view of targets and witnesses of such cases, cover-up is central to reducing a backlash. The basic means of cover-up is police lying about what happened: "Far too many officers lie with impunity about the conduct of a defendant, about what they were able to observe, and about whether proper procedures were followed" (Ogletree et al. 1995, p. 57).

Other police often know that their colleagues are lying but decline or refuse to speak out against them. This so-called "code of silence" — sometimes called the "blue wall of silence" — is a form of police loyalty that inadvertently can sanction abuse (Ogletree et al. 1995, pp. 
72-76; Quinn 2005; Skolnick and Fyfe 1993, pp. 108-112). The code of silence was a feature of the Los Angeles Police, like many other forces. As described by the Christopher Commission, set up in response to the King beating, the code of silence "consists of one simple rule: an officer does not provide adverse information against a fellow officer" (Christopher et al. 1991, p. 168). The code of silence is part of the culture of many police departments, but it is also enforced by reprisals against those who speak out, as described later in the section on intimidation.

Of crucial importance in the cover-up or exposure of police misconduct is the role of the media. In the conventional social science view of the news, the "official dominance model," officials are the primary definers of events. Consequently, most police use-of-force incidents are never mentioned in the news, and even those that are covered typically receive only cursory treatment, with the official versions of events predominating (Lawrence 2000, pp. 2829). In most cases journalists do not even find out about police use-of-force incidents, and many cases do not conform to usual news values. For example, only a minority of police shootings in the U.S. are reported (p. 29).

The interaction of official lying, the police code of silence, police public relations techniques, and the orientation of most news to official sources operates to minimize attention to most cases of alleged police brutality. These processes serve, in effect, as means of coverup.

Regina Lawrence (2000), in her highly sophisticated analysis of media treatment of police use of force, argues that a few exceptional events break through the usual elite-oriented framing of news. The King beating is the most prominent example of an alternative, eventdriven media treatment of police use of force. She argues that three factors combined to make the beating into an agenda-setting event: the video, a dramatic political struggle between LAPD Chief Daryl Gates and Los Angeles Mayor Tom Bradley, and public reaction (Lawrence 2000, pp. 62-85).

Though the King beating is the most dramatic exception to the usual pattern of cover-up, nonetheless there are some instances of attempted cover-up in its story. George Holliday, who made the video of the beating, rang the local police station saying he had witnessed a police beating, intending to offer the video. However, the desk officer expressed no interest in what Holliday had to say, nor did the officer record a complaint. Given this official unconcern, Holliday offered the tape to KTLA, a television station in Los Angeles (Christopher 1991, p. 11; Owens 1994, p. 56). In retrospect, it is possible to say that had the officer taken 
Holliday's call seriously and obtained the videotape, then destroyed it and claimed to have lost it, the scale of the backfire might have been dramatically reduced if not eliminated. Paul King, Rodney King's brother, attempted to make a complaint, but was given the brush-off. Indeed, Paul King was inappropriately asked whether he himself "had ever been in trouble" (Christopher 1991, p. 10; Owens 1994, p. 39). But for the videotape, no complaint about police misconduct might have been recorded.

\section{Devaluing the target}

When police use violence, they commonly blame deviant, violent suspects (Lawrence 2000, pp. 14, 37, 179). The beating of King was more likely to generate outrage if King was perceived as innocent, indeed exemplary, not only during his encounter with the Los Angeles police on March 3, 1991, but also before and after. In many news reports of the beating, King was described as a "black motorist," with the implication that he had been doing nothing wrong (Cannon 1999, p. 82). Others, though, emphasized King's shortcomings and transgressions, thereby devaluing him as a person and reducing backfire.

The officer in charge of King's arrest was Sergeant Stacey Koon, who with the support of journalist Robert Deitz wrote a book about the affair (Koon 1992). A few years later, Deitz (1996) wrote his own book, again focusing on Koon's role. Tom Owens, in contrast, was a former LAPD officer who became an investigator for prosecutions of police for misconduct. He was hired as investigator for King's initial legal team. His book (Owens 1994) gives a very different perspective. Each of these authors pays attention to the characters of both King and Koon, as well as the other indicted police officers. As might be expected, Koon's and Deitz's books are far more derogatory of King.

Koon was proud of the arrest; he considered it a model arrest and was initially pleased that it had been videotaped. In subsequent trials he justified every blow to King as appropriate and carried out according to official procedures. He is also forthright in mentioning a critical perspective on King.

The force we used was well within the guidelines of the Los Angeles Police Department; I'd made sure of that. And I was proud of my officers, proud of the professionalism they'd shown in subduing a really monster guy, a felony evader seen committing numerous serious traffic violations. And subduing this guy without the deadly force that 
all too often accompanies the arrest of a PCP-dusted felony suspect. (Koon 1992, p. 21).

Deitz (1996, pp. 31-60) wrote about “matters of character," lauding Koon's sterling record, giving extensive attention to King's failings, and claiming that King was treated with kid gloves by the police and courts because he was so well known through the video.

Owens (1994) gives an entirely different perspective. He describes various attempts to smear King by associating him with crimes or by framing him. On March 28, 1991, Los Angeles media reported that King was being investigated for two robberies early in the year, with the victims being shown photos of King by officers from the Foothills Division, where key police involved in the beating had worked (p. 103). Owens collected evidence that cleared King, concluding that the episode was a "set up by the LAPD meant to mitigate [sic] King's image, detract from his credibility and integrity, make the four cops look good by making King look bad" (p. 105).

Owens spends some time in his book telling of his personal interactions with King. While Owens certainly does not idolize King - he tells of King's crimes and impulsive and dangerous behavior - he does describe good sides to King, for example King spontaneously spending time with a group of kids, encouraging them to get an education and buying them ice creams (p. 151). Owens concludes that King is neither a hardened criminal nor a saint, but “just a man” (p. 152). In humanizing King, Owens counters others' denigration. In the first trial, King did not testify, making it easier for the defense to demonize him; in the second trial, he did testify, making him more human to the jury (Cannon 1999, pp. 427-28).

There is no doubt that King is an easy target for denigration, given his limited literacy, his arrest and prison record, and his penchant for drinking and fast driving. In a 1992 article in Vanity Fair, King's failings are recounted, along with criticisms of his lawyer and others cashing in on the "Rodney King trade" (Boyer 1992). In an article about yet another arrest of King on August 27, 2003, Horowitz (2003) defends the LAPD, criticizes "liberals," and denigrates King, calling him "a self-destructive lout," "a pathetic bum," and "a reckless criminal." The struggle over the meaning of the beating, including the reputation of the target, thus continues long after the event. 


\section{Reinterpreting the event}

If backfire can result from a perceived injustice, then an effective way to counter it is to convince people that what happened was not actually what it seemed. In the case of King, most people perceived a brutal police beating of an outnumbered and defenseless man. Police countered this with a different story: that King was a powerful and potentially dangerous threat to the police and that they had followed procedures in arresting him.

Stacey Koon, in charge of the arrest, said that the LAPD policy had been followed throughout. The policy specifies a series of options, with escalating use of force: presence; verbalization; commands; firm grips; pain compliance; impact techniques; and deadly force (Skolnick and Fyfe 1993, pp. 37-42). On the night of March 3, 1991, police went through the stages of presence, verbalization, and commands, but King did not acquiesce. Koon ordered a "swarm": four officers each grabbed one of King's arms or legs, but he threw them off. Then Koon used two tasers, whose high-voltage shocks normally bring down the target, but King, unlike most people hit with tasers, was not subdued; he made a charge at officer Powell. Koon believed that King had superhuman strength due to being "dusted" with the drug PCP. Next on the list of force options was impact techniques. Koon instructed two officers to use their batons on King; policy insists that there be occasional pauses between strikes to observe whether the suspect is complying, in which case a lower-force option can be adopted. But, said Koon, King did not adopt the fully prone position demanded by the police; the beating continued until he did. Koon said that the arrest was undoubtedly brutal, but it followed procedure (Koon 1992, pp. 25-52; see also Deitz 1996, pp. 61-91).

Because the police adopt force options in response to the suspect's behavior, the police attribute their own actions to the suspect. Koon claimed that "I had been in charge of the officers, but Rodney King had been in charge of the situation" (p. 45). This theme of King being "in charge" was used by the defense throughout the trials and nicely captures the reinterpretation involved. Normally, "in charge" implies having power or authority, which the police certainly had during the arrest. By portraying King as being "in charge" — validly so, from the perspective of police use-of-force options - the responsibility for the beating was attributed to King. More generally, the defense tried to make King the focus of attention, not the police (Geller and Hemenway 1997, p. 186). In the initial Simi Valley trial, the jurors accepted the police framing of events, finding the four officers on trial not guilty (Osborne 1992). 
The police thus blamed King for his own beating, whereas most viewers of the video blamed the police. But "the police" has multiple meanings: it could mean the four police directly involved in the arrest, the 20 or so other police at the scene who did not intervene, the Los Angeles police force generally, the LAPD as an organizational entity, or LAPD top officials - especially chief Daryl Gates - who were formally responsible for policies, training, and discipline. The popular and political response to the beating opened some divisions between these groups. Gates (1992, p. 316) referred to the beating as an "aberration," blaming the individual officers. The Christopher Commission took a more structural view, examining police attitudes, complaint procedures, and official tolerance of brutality, concluding that "The problem of excessive force in the LAPD is fundamentally a problem of supervision, management, and leadership" (Christopher et al. 1991, p. 32). Koon blamed not only King but also LAPD managers, especially Gates, as self-interested bureaucrats who protected themselves at the expense of street cops (Koon 1992, pp. 105-9). Some commentators agreed: Cannon (1999, p. 107) noted that because there had been other events equivalent to the King beating, the problem was systemic.

\section{Using official channels}

One way to reduce the popular outcry from injustice is to refer the matter to official bodies or experts that have a reputation for being independent and fair; commissions of inquiry are commonly set up after prominent incidents of police violence (Ross 2000, pp. 6, 38-44). If people believe that justice will be done, they are less likely to take matters into their own hands; for example, they will be less likely to join a protest group or take direct action.

The King beating was seen by many as a blatant injustice, leading to demands and expectations that justice be done, with a range of possibilities for obtaining "justice" expressed, including penalties for the police involved in the beating, resignation of police chief Gates, reform of the police to reduce brutality and penalize its perpetrators, and new policies to redress the economic and political disadvantage of poor minority inner-city communities in Los Angeles and elsewhere. The meaning of justice in part depended on whether a person saw the beating as an isolated incident or as a symptom of systemic problems, and on which of the “multiple publics" the person was a member (Jacobs 2000).

Within days of the screening of the Holliday video, a grand jury was formed to look into the beating. This was followed by initiation of an FBI investigation and by the indictment of 
four Los Angeles police officers (Cannon 1999). These uses of formal procedures focused on the police involved in the beating, but pressure was intense for more sweeping reforms. Calls for chief Gates to resign reflected an assumption that new policies would be implemented. At the end of March 1991, Gates formed a commission to investigate the beating; at the same time, mayor Tom Bradley also formed one. By agreement of the two bodies, they combined to form the Christopher Commission, which carried out a thorough investigation in a matter of months, reporting in early July (Cannon 1999). The commission did not examine the culpability of individual officers for the beating, which was a matter for the courts, but instead reported on systemic problems in the LAPD: the use of excessive force, racism and bias, police culture, recruitment and training, complaint systems, and formal structures for control of the police department and its chief. The commission's report (Christopher et al. 1991) was seen by many as a largely sound and far-sighted document which, if its recommendations were implemented, would transform the police (Cannon 1999, pp. 121-47). (In contrast, Gates (1992, pp. 347-51) was very critical of the report.) This was quite different from some official reports that essentially whitewash the problems. After release of the report, pressure mounted on Gates to resign; eventually he announced he would step down in 1992.

Attracting far more attention was the trial of the police officers directly involved in the beating (Cannon 1999). All four were charged with assault by force and with unnecessarily beating a person under color of authority, Koon and Powell with submitting a false police report, and Koon with being an accessory after the fact (Geller and Hemenway 1997, pp. 164165, 316-317). Nearly everyone - the public, journalists, lawyers, and the defendants expected a guilty verdict on at least some of the charges. Hence, news of the verdict of not guilty for all four officers acted like a shock wave through the country and especially through South Central Los Angeles. The massive riot that ensued can be attributed, in part, to outrage over justice denied or, in other words, to an extension of the original backfire over the King beating.

On the third day of the riots, President George Bush addressed the nation on television and "virtually promised federal prosecution of the acquitted police officers ... the president and the attorney general felt the prosecutions were politically imperative" (Cannon 1999, p. 374; see also Deitz 1996, pp. 96-98). According to Cannon, the government's goal was preventing "far-reaching investigations into police conduct" and "defusing the concerns of civil rights activists" (p. 375). Enormous government resources were poured into the federal trial of the same four officers; with a different venue and jury composition, plus enormous pressures on 
the jurors to reach a guilty verdict to prevent further riots, the result was that two of the four officers were found guilty and sent to prison. The system appeared to work and this time no riots or disturbances occurred (Cannon 1999).

The two criminal prosecutions of the four officers received saturation media coverage; far less media attention was given to system reform in the LAPD. In part this reflects news values that give priority to personalities and conflict. The net effect was to personalize the provision of justice and divert attention away from system reform.

To point to the role of official channels in reducing backfire is not to reject official channels, especially when they can bring about real change. The point here is that official channels can be used, cynically or inadvertently, to reduce backfire from a perceived injustice. The media are offered "a ritual of normalization in which problems are identified but then handed off to officials to resolve" (Lawrence 2000, p. 113). In terms of narrative analysis, the government's initiatives in setting up a commission and holding trials served to retain a romantic narrative with the government as hero (Jacobs 1996, p. 1252).

\section{Intimidation and bribery}

Police abuses are often accompanied by intimidation: the victim may be threatened or arrested. "Far too frequently, the citizen who has just been subjected to police abuse is then arrested and charged with a variety of crimes" (Ogletree et al. 1995, p. 42). Sometimes witnesses are charged as well. Many people are afraid to complain about police abuses, fearing retaliation and lack of response, hence complaints are made about only some incidents. Police discourage complaints by resisting the filing of them, by harassing the complainant, by making threats, and by making arrests. For example, "In Virginia Beach, an NAACP attorney was arrested and prosecuted for trespass when he went to the police station to file a complaint about police misconduct toward an NAACP observer at a major disturbance" (p. 56). Police may also sue citizens who they allege are making false allegations about police misconduct, an example of Strategic Lawsuits Against Public Participations (SLAPPs) (Pring and Canan 1996). Most of this intimidation by police is made more effective by being behind the scenes; cover-up and intimidation go hand in hand.

Bribery is another tool to limit backfire. When citizens sue police over alleged misconduct, the result is often a settlement in which the citizen receives a pay-out but in return signs a confidentiality agreement that restricts public comment on the case. 
Evidence about intimidation and bribery can be hard to obtain, given the reluctance of targeted individuals to talk and the interest of the police in keeping the issue quiet. In the King case, the most extensive account of intimidation is given by Tom Owens (1994), the former LAPD officer who became an investigator for King's legal team.

It seemed every time someone on our side became publicly known, confidential information about that person's background surfaced. Within two days of appearing at a press conference, a doctor who had initially scheduled various specialists to work with King became the target of a minor scandal. Confidential information about an alleged past problem of the doctor's - an overbilling to an insurance company - was leaked to the media 'from an informed source.' As quickly as the smear was out, the doctor resigned from the team. (p. 32).

Owens tracked down quite a number of witnesses to the beating of King, most of whom were reluctant to comment, much less testify, due to fear of reprisals (pp. 93-94, 99-101, 112). Freddie G, one of the two passengers in King's car during the chase before the beating, was killed a few months later in a car crash. Owens spoke to witnesses who said the car was run off the road (p. 119).

Police and others who spoke out critically about the LAPD and chief Gates suffered threats and harassment (pp. 182-87, 249). Police use-of-force experts were highly reluctant to testify at the trials of the four officers: the police code of silence was backed up by reprisals, especially ostracism (pp. 186-87). Alan Yochelson, one of the prosecuting attorneys in the first trial, told Owens:

... we talked to any number of other force and policy experts, who told us the video showed excessive force. Clearly, there was excessive force on that video, but none of them would go on the record. They said it would end careers. (p. 266).

Lou Cannon (1999), in his mammoth account of the King beating and its aftermath, reports some of the same findings as Owens. Cannon recounts how LAPD use-of-force experts refused to testify at the Simi Valley trial. Fred Nichols, who had testified to excessive force at the grand jury, did everything possible to avoid testifying in court, including resisting a subpoena by claiming to suffer stress (pp. 237-38). In the second, federal, trial, LAPD use-of- 
force expert Mark Conta testified for the prosecution and was subsequently ostracized by fellow officers; Koon called him a "whore" (pp. 416-17). [Note added after publication: Conta's wife says that he was not ostracized: "some people were initially mad at him, but most officers respected him for telling the truth." Kathy Conta, personal communication, 13 June 2006.] One of the four officers involved in the beating, Theodore Briseno, testified against his fellow officers. He was labeled "Benedict Briseno"; the LAPD later instigated an investigation of Briseno for perjury (p. 598).

As noted, intimidation is difficult to document, but even more so is bribery. Were police who adhered to the code of silence and refused to testify against fellow officers rewarded with collegial support, better assignments, or promotions? The processes involved are often unconscious, so producing documentation is extremely difficult. Bribery may be too strong a word to describe the process of rewarding those who do not speak out about an injustice.

\section{Conclusion}

The King beating offers an exceptionally rich and vivid case study showing how what is perceived as an attack can backfire. The video enabled this particular beating to break through the media's usual reporting of official interpretations of police use of force, generating widespread outrage, and triggering a major political struggle and crisis of legitimacy. The case provides ample evidence of five methods for inhibiting outrage: covering up the attack; devaluing the target; reinterpreting the events; using official channels; and using intimidation. This evidence shows that the backfire model, developed out of the study of violent attacks on nonviolent protesters, can usefully be applied to police use of force.

Cover-up is a highly potent technique of inhibiting outrage. This suggests that reformers and activists should devote attention to means of exposing abuses. Skolnick and Fyfe (1993, p. 266) adopt openness as a key principle of police reform, arguing that "we should routinely videotape police conduct during those occasions where propensity to excessive force are most likely to occur: high-speed chases, interrogations, protests, and riots," a recommendation endorsed by Ross (2000, p. 126), though it is important to remember that all videotapes are open to manipulation and interpretation. Other means of challenging cover-ups are to support investigative journalism and encourage whistleblowers, something especially challenging and important for police departments where the code of silence reigns. 
Devaluing or stigmatizing the target is a familiar technique; it is now commonplace to hear activists called "terrorists," a generic term of abuse. More long-standing is devaluation of groups such as people with disabilities, ethnic minorities, the poor, the unemployed, and people with criminal records (Ryan 1972; Wolfensberger 1972). Opposing devaluation is not easy. Those who are concerned about justice to all, regardless of status or stigma, need to be aware of techniques of devaluation, to be prepared to expose it, and to argue that everyone deserves to be treated with dignity and fairness.

Struggles over interpretations of events are a central feature of communication, from news to gossip, so it is not surprising that interpretation struggles are central to backfire dynamics. What is important to note is that interpretation struggles can persist long after an apparently uncontestable documentation such as the Holliday video. News stories and interpersonal communications - from backyard conversations to chatrooms - are all part of interpretation struggles, which can carry on for months, years, or decades. For many activists, participation in protests seems more real and substantial than writing a letter to the editor; looking at backfires suggests that interpretation struggles can be as crucial to the impact of social action as the immediate action itself.

Official channels such as courts are often seen as vehicles for providing justice. Analysis of backfire dynamics leads to a rather different view: official channels can be potent tools for dissipating popular outrage against injustice. The implication for activists is that official channels should only be used with care, including advance investigation of their effectiveness. Someone studying the fate of complaints against the police - nearly all of which exonerate the police of any wrongdoing - might conclude that it would be far more effective to write a letter to the newspaper, circulate a leaflet, or call a meeting. As argued by Lawrence (2000), mobilization of popular concern is a key reason why the King beating received such intense media coverage.

Finally, intimidation and bribery can be potent tools for inhibiting backfire, but they are seldom studied. Police brutality is often accompanied by threats and arrests of the victims, a process that has strong links with cover-ups. More widely, many activists and movements have been targeted for harassment and disruption, but there is relatively little written on how to deal with this (Glick 1989). Preparation is crucial, as is refusal to be intimidated and willingness to expose threats and attacks.

There is much more to learn about backfire dynamics by looking at individual cases, both where backfire occurs and where it is largely inhibited. It is worth looking at backfire in a range 
of arenas, including censorship seen as an attack on free speech (Jansen and Martin 2004), torture (Martin and Wright 2003), terrorism, war (Martin 2004), and genocide. By comparing diverse cases, insights can be gained about common characteristics and idiosyncratic features. Studying backfire dynamics thus can lead to ideas on how to promote action to deal with injustice.

\section{Acknowledgments}

I thank Don Eldridge, Jeff Ross, Barbara Sims, and an anonymous reviewer for valuable comments on drafts of this paper and Truda Gray, David Hess, Hannah Lendon, George Matheson, David Mercer, and Greg Scott for helpful discussions. This research was supported by the Australian Research Council.

\section{References}

Bandura, Albert. 1986. Social Foundations of Thought and Action: A Social Cognitive Theory. Englewood Cliffs, NJ: Prentice-Hall.

Berger, Peter L., and Thomas Luckmann. 1966. The Social Construction of Reality. Garden City, NY: Doubleday.

Boyer, Peter J. 1992. “The Selling of Rodney King,” Vanity Fair (June):78-82, 158-61.

Butler, Judith. 1993. "Endangered/Endangering: Schematic Racism and White Paranoia.” Pp. 15-22 in Reading Rodney King/Reading Urban Uprising, edited by Robert GoodingWilliams. New York: Routledge.

Cannon, Lou. 1999. Official Negligence: How Rodney King and the Riots Changed Los Angeles and the LAPD. Boulder, CO: Westview.

Christopher, Warren, et al. 1991. Report of the Independent Commission on the Los Angeles Police Department. Los Angeles: Independent Commission on the Los Angeles Police Department.

Deitz, Robert. 1996. Willful Injustice: A Post-O.J. Look at Rodney King, American Justice, and Trial by Race. Washington, DC: Regnery.

Frankel, Philip. 2001. An Ordinary Atrocity: Sharpeville and its Massacre. New Haven, CT: Yale University Press.

Fukuda, Chisako M. 2000. "Peace through Nonviolent Action: The East Timorese Resistance Movement's Strategy for Engagement." Pacifica Review 12(1):17-31. 
Gates, Daryl F. with Diane K. Shah. 1992. Chief: My Life in the LAPD. New York: Bantam.

Geller, Laurence H. and Peter Hemenway. 1997. Last Chance for Justice: The Juror's Lonely Quest. Dallas: NCDS Press.

Glick, Brian. 1989. War at Home: Covert Action against U.S. Activists and What We Can Do about It. Boston: South End Press.

Gooding-Williams, Robert, ed. 1993a. Reading Rodney King/Reading Urban Uprising. New York: Routledge.

Gooding-Williams, Robert, 1993b. “'Look, a Negro!'” Pp. 157-77 in Reading Rodney King/Reading Urban Uprising, edited by Robert Gooding-Williams. New York: Routledge.

Goodwin, Charles. 1994. "Professional Vision.” American Anthropologist 96(3):606-33.

Horowitz, David. 2003. "Rodney King: Once a Bum, Always a Bum," FrontPageMagazine.com (September 9) [http://www.frontpagemag.com/Articles/ ReadArticle.asp?ID=9712].

Jacobs, Ronald N. 1996. "Civil Society and Crisis: Culture, Discourse, and the Rodney King Beating." American Journal of Sociology 101(5):1238-72.

Jacobs, Ronald N. 2000. Race, Media, and the Crisis of Civil Society: From Watts to Rodney King. Cambridge: Cambridge University Press.

Jansen, Sue Curry and Brian Martin. 2003. "Exposing and Opposing Censorship: Backfire Dynamics in Freedom-of-Speech Struggles.” Pacific Journalism Review 10(1):29-45.

Kohen, Arnold S. 1999. From the Place of the Dead: The Epic Struggles of Bishop Belo of East Timor. New York: St. Martin's Press.

Koon, Stacey C. with Robert Deitz. 1992. Presumed Guilty: The Tragedy of the Rodney King Affair. Washington, DC: Regnery.

Lasley, J. R. 1994. “The Impact of the Rodney King Incident on Citizen Attitudes toward Police." Policing and Society 3:245-55.

Lawrence, Regina G. 2000. The Politics of Force: Media and the Construction of Police Brutality. Berkeley: University of California Press.

Martin, Brian. 2004. “Iraq Attack Backfire.” Economic and Political Weekly 39(16):1577-83.

Martin, Brian and Steve Wright. 2003. "Countershock: Mobilizing Resistance to Electroshock Weapons." Medicine, Conflict and Survival 19(3):205-22.

McMillan, Andrew. 1992. Death in Dili. Sydney: Hodder and Stoughton. 
Moore, Barrington, Jr. 1978. Injustice: The Social Bases of Obedience and Revolt. London: Macmillan.

Ogletree, Jr., Charles J., Mary Prosser, Abbe Smith and William Talley, Jr.; Criminal Justice Institute at Harvard Law School for the National Association for the Advancement of Colored People. 1995. Beyond the Rodney King Story: An Investigation of Police Misconduct in Minority Communities. Boston: Northeastern University Press.

Omi, Michael and Howard Winant. 1993. "The Los Angeles 'Race Riot' and Contemporary U.S. Politics.” Pp. 97-114 in Reading Rodney King/Reading Urban Uprising, edited by Robert Gooding-Williams. New York: Routledge.

Osborne, D. M. 1992. "Reaching for Doubt.” American Lawyer (September): 62.

Owens, Tom with Rod Browning. 1994. Lying Eyes: The Truth behind the Corruption and Brutality of the LAPD and the Beating of Rodney King. New York: Thunder's Mouth Press.

Pring, George W. and Penelope Canan. 1996. SLAPPs: Getting Sued for Speaking Out. Philadelphia: Temple University Press.

Quinn, Michael W. 2005. Walking with the Devil: The Police Code of Silence. Minneapolis, MN: Quinn and Associates.

Ross, Jeffrey Ian. 2000. Making News of Police Violence: A Comparative Study of Toronto and New York City. Westport, CT: Praeger.

Ryan, William. 1972. Blaming the Victim. New York: Vintage.

Sharp, Gene. 1973. The Politics of Nonviolent Action. Boston: Porter Sargent.

Sigelman, Lee, Susan Welch, Timothy Bledsoe and Michael Combs. 1997. "Police Brutality and Public Perceptions of Racial Discrimination: A Tale of Two Beatings." Political Research Quarterly 50(4):777-91.

Skolnick, Jerome H. and James J. Fyfe. 1993. Above the Law: Police and the Excessive Use of Force. New York: Free Press.

Sykes, Gresham M. and David Matza. 1957. "Techniques of Neutralization: A Theory of Delinquency." American Sociological Review 22(6):664-70.

Wolfensberger, Wolf. 1972. The Principle of Normalization in Human Services. Toronto: National Institute on Mental Retardation. 